\title{
Pedosedimentary records of Holocene paleoenvironments in a dryland alluvial fan system in Sonora, NW-Mexico
}

\author{
Registros pedosedimentarios de paleoambientes del Holoceno en abanicos aluviales de zonas \\ secas de Sonora, NO-México \\ Registos pedosedimentares de paleoambientes do Holocénico em sistemas secos de cones aluvionares \\ em Sonora, $N W$-México
}

\section{AUTHORS}

Ibarra G. ${ }^{@, 1}$

gigiotes81@yahoo. com.mx

\section{Solleiro-Rebolle- do E. ${ }^{2}$}

\section{Ayala E. ${ }^{1}$}

\section{Cabadas $\mathrm{H}^{3}$}

\section{López-Martínez R. $^{2}$}

\section{@ Corresponding Author}

${ }^{1}$ Posgrado en Ciencias de la Tierra, Universidad Nacional Autónoma de México. 04510 Ciudad de México, México.

${ }^{2}$ Instituto de Geología Universidad Nacional Autónoma de México. México

${ }^{3}$ Facultad de Geografía, Universidad Autónoma del Estado de México. México

Received: 05.05.2017 | Revised: 09.06.2018 | Accepted: 12.06.2018

\section{ABSTRACT}

In this work we present a detailed micromorphological analysis of a sequence of palaeosols and sedimentary units at La Playa archaeological site. This sequence is from the Late Pleistocene (Marine Isotopic Stage 2) to the Late Holocene. Complementing the micromorphological study, a geomorphological analysis is provided, in order to establish the origin of the landscape units. The results show that according to the geomorphology, La Playa constitutes an alluvial fan, formed by a complex, braided channel. The older unit, the San Rafael Palaeosol (SRP) is the most developed and has a set of features associated with the changing paleoenvironmental conditions such as weathering of the primary minerals, clay illuviation (evidencing humid conditions of the Terminal Pleistocene), pedogenic carbonate accumulation in the A horizon (related to dry environments of Altithermal). The SRP is buried by fluvial sediments, which include different facies interpreted as: floodplain, sandbars, and channels. These sedimentation events are associated with the end of the Altithermal period and evidence more active geomorphic processes, probably due to strong storms causing flooding and the migration of the main tributary. Above the sedimentary unit, the Boquillas Palaeosol (BOP), formed during the Late Holocene, is derived from fluvial-alluvial deposits causing a synsedimentary soil, with a more incipient development as indicated by micromorphological features.

\section{RESUMEN}

En este trabajo presentamos un detallado análisis micromorfológico de una secuencia de paleosuelos y unidades sedimentarias en el sitio arqueológico La Playa. Esta secuencia se forma desde el Pleistoceno superior (Etapa Isotópica Marina 2) hasta finales del Holoceno. Complementando el estudio micromorfológico se proporciona un análisis geomorfológico para establecer el origen de las unidades paisajisticas. Los resultados muestran que de acuerdo con la geomorfología, La Playa constituye un abanico aluvial constituido por un complejo canal trenzado. La unidad más antigua, el Paleosuelo San Rafael (SRP) es la más desarrollada y tiene un conjunto de características asociadas a los cambios en las condiciones paleoambientales tales como la meteorización de los minerales primarios, iluviación de arcilla (que evidencian las condiciones huimedas de finales del Pleistoceno), acumulación de carbonatos pedogénicos en el horizonte A (relacionados con los ambientes secos del Altitermal). El SRP está enterrado por sedimentos fluviales, que incluyen diferentes facies interpretadas como: llanuras de inundación, barras de arrena y canales. Estos eventos de sedimentación se asocian al final del periodo Altitermal y evidencian procesos geomórficos más activos, probablemente debido a fuertes tormentas que causaban inundaciones y la migración del principal afuente. Por encima de la unidad sedimentaria, el Paleosuelo Boquillas (BOP), formado durante finales del Holoceno, se deriva de depósitos fuvio-aluviales originando un suelo sin-sedimentario, con un desarrollo más incipiente como lo indican las características micromorfológicas. 


\section{RESUMO}

Neste trabalho apresenta-se uma análise micromorfológica detalhada de uma sequência depaleossolos e unidades sedimentares do sítio arqueológico de La Playa. Esta sequência formou-se desde o Plistocénico superior (Etapa Isotópica Marina 2) até aos finais do Holocénico. Complementando o estudo micromorfológico apresenta-se uma análise geomorfológica para estabelecer a origem das unidades de paisagem. Os resultados mostram que de acordo com a geomorfologia, La Playa constitui um cone aluvionar, constituído por um complexo canal entrançado. A unidade mais antiga, o Paleossolo San Rafael (SRP) éa mais desenvolvida e tem um conjunto de características associadas às alteraçôes das condiçôes paleoambientais, tais como a meteorização dos minerais primários, iluviação de argila (que evidenciam as condiçôes húmidas do final do Plistocénico), acumulação de carbonatos pedogenéticos no horizonte A (relacionados com os ambientes secos do Altitérmico). O SRP está coberto por sedimentos fuviais, que incluem diferentes fácies interpretados como: planícies de inundação, barras de areia e canais. Estes eventos de sedimentação estão associados ao final do periodo Altitérmico e evidenciam processos geomorfológicos mais ativos, provavelmente devidos a fortes tempestades que causaram inundaçöes e a migração do afluente principal. Acima da unidade sedimentar, o Paleossolo de Boquillas (BOP), formado durante os finais do Holocénico, deriva de depósitos fluvio-aluvionares originando um solo sin-sedimentar, com um desenvolvimento mais incipiente como é indicado pelas suas caracteristicas micromorfológicas.

\section{Introduction}

Paleoenvironmental research in the northwest Mexico (extracted from different archives) has documented that during the Marine Isotope Stage (MIS) 2 (Last Glacial Maximum and late Glacial) the climate was more humid and cooler than today (Betancourt et al. 1990; Metcalfe et al. 1997, 2002; Ortega-Ramírez et al. 1998; Holgrem et al. 2003; Nordt 2003). On the contrary, the Holocene climate was characterized by an aridity trend that ended with the modern environmental conditions. The driest and warmest conditions prevailed during the Altithermal period (7,500 to 4,500 cal BP), which was defined by Antevs (1948), a period of severe aridity and drought, accompanied by intense erosion. The importance of this stage in SW United States - Northwest Mexico is the adaptive response of humans groups to such conditions (Meltzer 1999).

Several studies for the NW Mexico and S-SW United States have documented dry and warm conditions during that period (Gile and Grossman 1968; Nettleton et al. 1975; Byrne et al. 1979; Weide 1985; Holliday 1989; Smith and McFaul 1997). However, questions are still unanswered, such as: How warm and dry was this period? How did these environmental conditions impact human settlements? Were these conditions identical in the entire region (NW Mexico and SW United States)?

La Playa archaeological site, located in Sonora, NW Mexico, has a long history of human occupation (Carpenter et al. 2005; Carpenter 2009) and a well preserved record of palaeosols formed during the Late Pleistocene and the Holocene (Cruz-y-Cruz et al. 2014). It represents a promising locality to document the regional environmental change in the Altithermal. Copeland et al. (2012) has established the stratigraphy of the Holocene units (Units $\mathrm{B}$ and $\mathrm{C}$ ) concluding that the interaction between humans and the environment was 
very dynamic and that the increase in the settlements was driven by the favorable conditions occurring just after the Altithermal period. The paleopedological record at La Playa has shown two different pedogenetic pathways: one belonging to the Late Pleistocene-Middle Holocene (> 15,000 to 4,000 cal BP), characterized by the San Rafael Palaeosol (SRP); and another for the Late Holocene $(<4,000$ cal BP), when the Boquillas palaeosol (BOP) formed (Cruz-y-Cruz et al. 2014). These two pedogenetic pathways do not evidence contrasting climatic conditions between the two periods of soil fomation, but longer periods of landscape stability.

In consequence, the objective of this work is to reconstruct the environmental conditions that promote the formation of paleosols and sedimentary units at different scales of observation from landscape to micromorphology. With this information, to understand the interaction between the geomorphic processes related to stages of stability (when paleosols are formed) and instability (when sedimentation occurs) and the environmental conditions during the Altithermal period, contributing to a better understanding of the paleoenvironmental mosaic of the NW of Mexico.

\section{Material and Methods}

\subsection{Characteristics of the study area}

La Playa is located in Sonora state, northwest Mexico (Figure 1). The geology of the site is characterized by Late Cretaceous metasedimentary rocks (McLaurin et al. 2012). These rocks outcrop at the mountain crests (Sierra Boquillas), whereas extensive Quaternary alluvial sediments cover lower areas. The average annual temperature ranges from 18 to $22{ }^{\circ} \mathrm{C}$ and the average annual precipitation is 200 to $400 \mathrm{~mm}$, with rainfall occurring between summer and winter (Vidal-Zepeda 2005). The predominant vegetation is desert shrub type, represented by mesquite (Prosopis spp.), palo verde (Crecidium spp.), ironwood (Oloseya tesota), chollas and nopales (Opuntia), ocotillo (Focequieria splen- dens), saguaro (Carnegiea gigantae), pitahaya (Lemaireocerus turberi), vinoramas (Acacia aniantecea), candles and cat's claw (Mimosa spp.), vegetation of low hills and ridges (Pérez 1985).

The site has been extensively investigated because of the abundance of fossils of Pleistocene fauna such as prairie dog (Cynomys Iudovicianus), bison, mammoths, camel (cf. Camelops), pronghorn (Capromeryx sp.) and tortoises (Hesperotestudo sp). (Mead et al. 2010), as well as archaeological material of early human occupation (Villalpando and Carpenter 2004; Carpenter et al. 2009). However, most of the human evidence belongs to the last 3,000 years (Carpenter et al. 2005; Carpenter 2009; Copeland et al. 2012).

La Playa, an alluvial fan or a fine-grained alluvial floodplain as described by Schott (2017), has an extension of at least $10 \mathrm{~km}^{2}$ on both sides of the Río Boquillas. Today, the Río Boquillas is dry for most of the year.

The main channel is in the western side of the area, near the Sierra. Before 1960, the Río Boquillas was less entrenched than today (Johnson 1960).

\subsection{Field survey}

A detailed study of two representative profiles of alluvial palaeosol-sedimentary sequences at La Playa archaeological site were selected for identification, description and sampling of the buried Late Quaternary palaeosols. It was supplemented by the geomorphological subdivision of the alluvial fan using satellite images. Further field palaeopedological surveys focused on the older geomorphological units and resulted in identifying exposures with the most complete sequences and best represented palaeosols and sedimentary units.

The location of the study area is shown in Figure 1. Field description is focused on the morphological features which indicate the grade and type of palaeosol pedogenesis (color pattern, structure, porosity, and pedofeatures) as well as other features related to the erosion and/or sedimentation processes (lamination, thickness of the soil horizons and the type of boundaries). 
Undisturbed blocks of soil for micromorphological research were taken from exposures of the palaeosol genetic horizons and associated sedimentary strata. All field descriptions and profile designations were based on the World Reference Base (IUSS Working Group WRB 2006). Soil samples were collected from each horizon, and were air-dried.

During the fieldwork over La Playa site, Cruz-yCruz et al. (2014) identifed areas covered by red weathered soils (Chromic Cambisols, according to IUSS Working Group WRB (2006)) that show clear discordance with the present day bioclimatic conditions. Here we present results from two new profiles: Zanja and Maravillas, and compare these with the Hornos 1 and 2; and Canal 2 profiles already studied by Cruz-y-Cruz et al. (2014).

At Hornos 1, the SRP, a Chromic Cambisol, represents the older phase of pedogenesis; at Hornos 1 and Canal 2, the BOP is a cummu- lic palaeosol, formed by several pedosediments and poorly developed palaeosols. The SRP is considered a marker for finding Late Pleistocene archaeological sites and megafauna localities. In contrast, BOP is related to the human occupation surface during the period of early agriculture, in the Middle Holocene. Both palaeosols, SRP and BOP are separated by silty sediment layers. In most cases, the top of the horizon is disturbed or eroded in these profiles.

The Zanja profile (30²9'57.40" N, 111031'55.89" W), at a distance of $320 \mathrm{~m}$ from the Hornos 1 profile, is described in a $1.10 \mathrm{~m}$ deep section exposed among various pedestals, where SRP showed a high degree of erosion. In some profiles, the Bw horizon is preserved and in others, the underlying Bk horizon is directly beneath the silt sediments, with no Bw and A horizons. At the studied Zanja profile, we have found the most complete profile of the SRP, which includes the A, Bw, and Bk horizons.

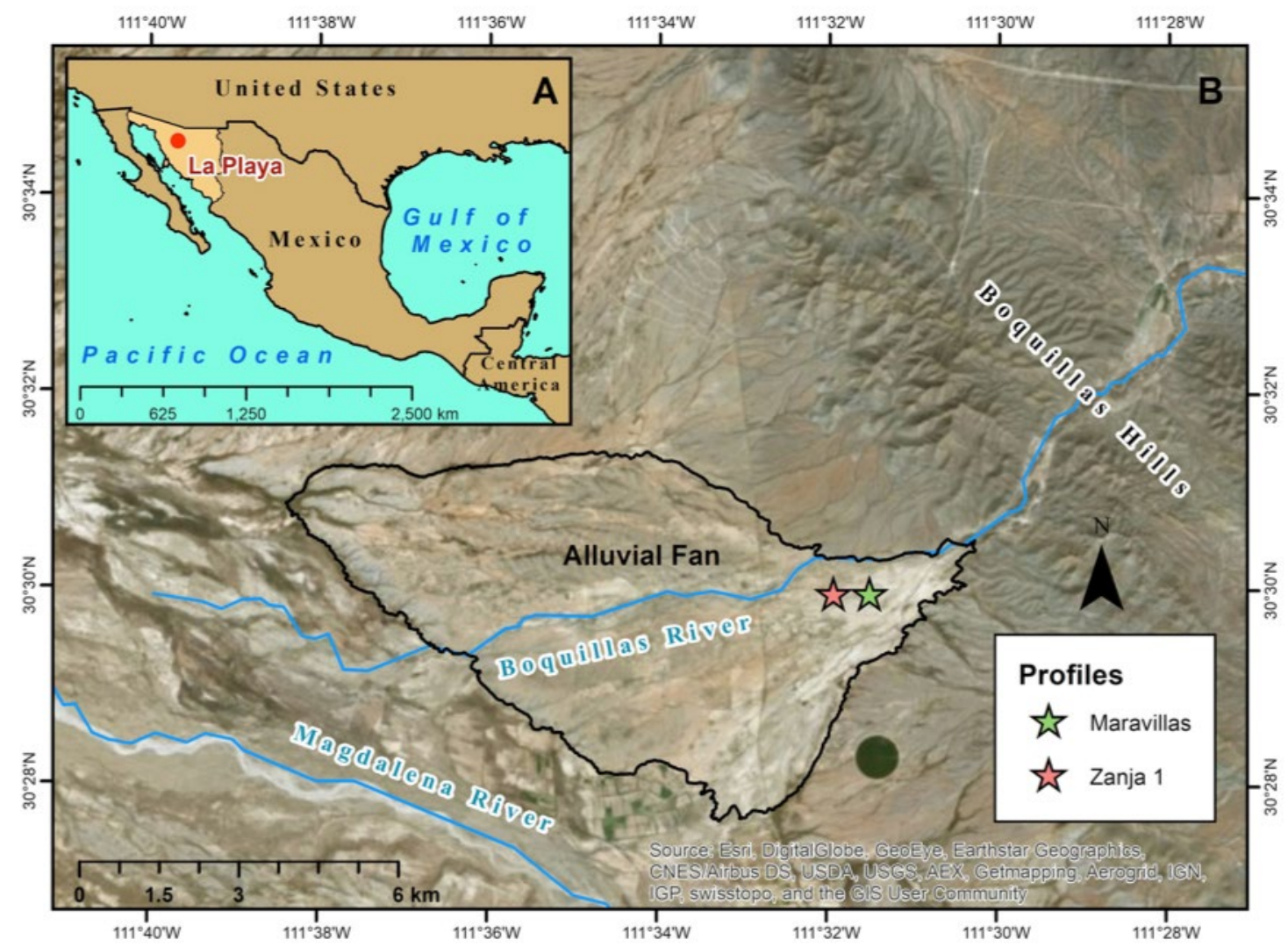

Figure 1. A) Location of the study site. B) The satellite image shows the location of profiles at La Playa site. Satellite image taken from Google Earth, modified by the authors. 
The Maravillas profile $\left(30^{\circ} 29^{\prime} 57.44 " \mathrm{~N}\right.$, $\left.111^{\circ} 31^{\prime} 30.41^{\prime \prime} \mathrm{W}\right)$ is located $364.5 \mathrm{~m}$ from Hornos 1 , at a gully. This profile is $3.66 \mathrm{~m}$ thick and shows the most complete sequence with three pedostratigraphic units: the SRP at the base, a thick sedimentary sequence, and the BOP on top. This upper part is formed in the Late Holocene and shows a strong affectation of anthropogenic processes (Copeland et al. 2012; Schott 2017).

2.3. The macro scale observations: geomorphology of the study site

The different landforms were outlined using satellite images and ArcGIS 10.3. Because of the flatness of the terrain, the topography was not the main aspect in recognizing individual landforms over the alluvial fan. Color and texture of the surface, the drainage pattern, the vegetation distribution and the limits between features were the criteria taken into account to delineate the most remarkable elements in the relief. The forms were classified according to Blair and McPherson (1994). To corroborate the units, established by image analyses, field observations were also considered. In this way, soil profiles from previous works as well as from this paper were used to correlate the identified features with those observed in the field.

2.4. Micromorphology of the palaeosol and sediments

For this analysis undisturbed samples were taken from nine horizons (BOP-2Ap and 3Ap; sedimentary unit-sandbars, floodplain and channel facies, 4AC, 4C, 5C; and SRP-7Bw) of the Maravillas profile; and four samples (2A1, 2A2, 2Bw1 and 2BCk horizons) of the Zanja profile. After air-drying, they were impregnated with polyester resin with a low viscosity and a refractive index of 1.5. After their hardening, they were cut to a thickness of 30 microns. The micromorphological observations were done with an Olympus petrographic microscope, using transmitted, polarized and reflected light, following the terminology of Bullock et al. (1985). The observations were especially focused on the features of pedogenic, sedimentary, and diagenetic processes, which help to trace stages of soil development and sedimentation/erosion and their spatial relation to the pedogenic features.

\subsection{Chronological framework}

To establish the age of the palaeosols, three samples were sent to International Chemical Analysis Inc. (ICA), Miami, Florida, for radiocarbon dating with AMS (Accelerator Mass Spectrometry), two from organic matter (Zanja-2A1, and Maravillas-4AC horizons), and one from pedogenic carbonates in the $2 \mathrm{BCk}$ horizon of the Zanja profile.

\section{Results}

\subsection{Landforms in the alluvial fan}

La Playa alluvial fan is located in a bajada system at southwestern piedmont of the Sierra Boquillas. The identified landforms with their individual features are described below (Figure 2):

a) Ancient alluvial fan. This lobe, found in the northern portion of the fan, has a slightly more elevated relief than the rest of the alluvial fan. This part is highly dissected and reflects the oldest fan. Its surface is reddish but covered by a greyish material; probably due to the redeposition of the SRP.

b) SRP surface. This Pleistocene reddish surface (Cruz-y-Cruz et al. 2014) is mainly distributed at the middle and distal part of the fan; the erosion in this landform has entirely removed the BOP and the surficial horizons of SRP. Furthermore, incisive channels affected the distal part. The SRP surface is flatter than the ancient alluvial fan. However, it is hard to know if it is older or both were formed at the same time.

c) BOP surface. This landform extents from the apex, near the Sierra Boquillas until eastern border of the fan. One of most conspicuous aspect of this unit is the presence of mounds or pedestals, which are the remains left by coalescent gullies that affect almost all the surface. The relief is also flat and is composed of sand and silt grains, often arranged in laminated layers of well sorted materials. The profiles found 
in this area are pedestals. Particularly in the central area, the SRP, the sedimentary unit, and BOP can be observed.

d) Colluvium. Landform restricted to the apex of the fan, consists of high energy deposits of rounded rocks inserted in a matrix of BOP. These deposits probably were transported by gravitational process due to their proximity to the mountain front and later partialy reworked by water. e) Fluvial deposits. These are deposits of cobbles and pebbles located on the margins of the feeder channel in the middle portion of the fan. They represent the highest energy segment of the fan and their development was contemporary to the BOP surface.

f) Modern feeder channel. The feeder channel is at the north of the fan between the ancient fluvial fan and the SRP and the BOP surfaces, dissecting the whole surface of the fan and creating lateral deposits of sand.

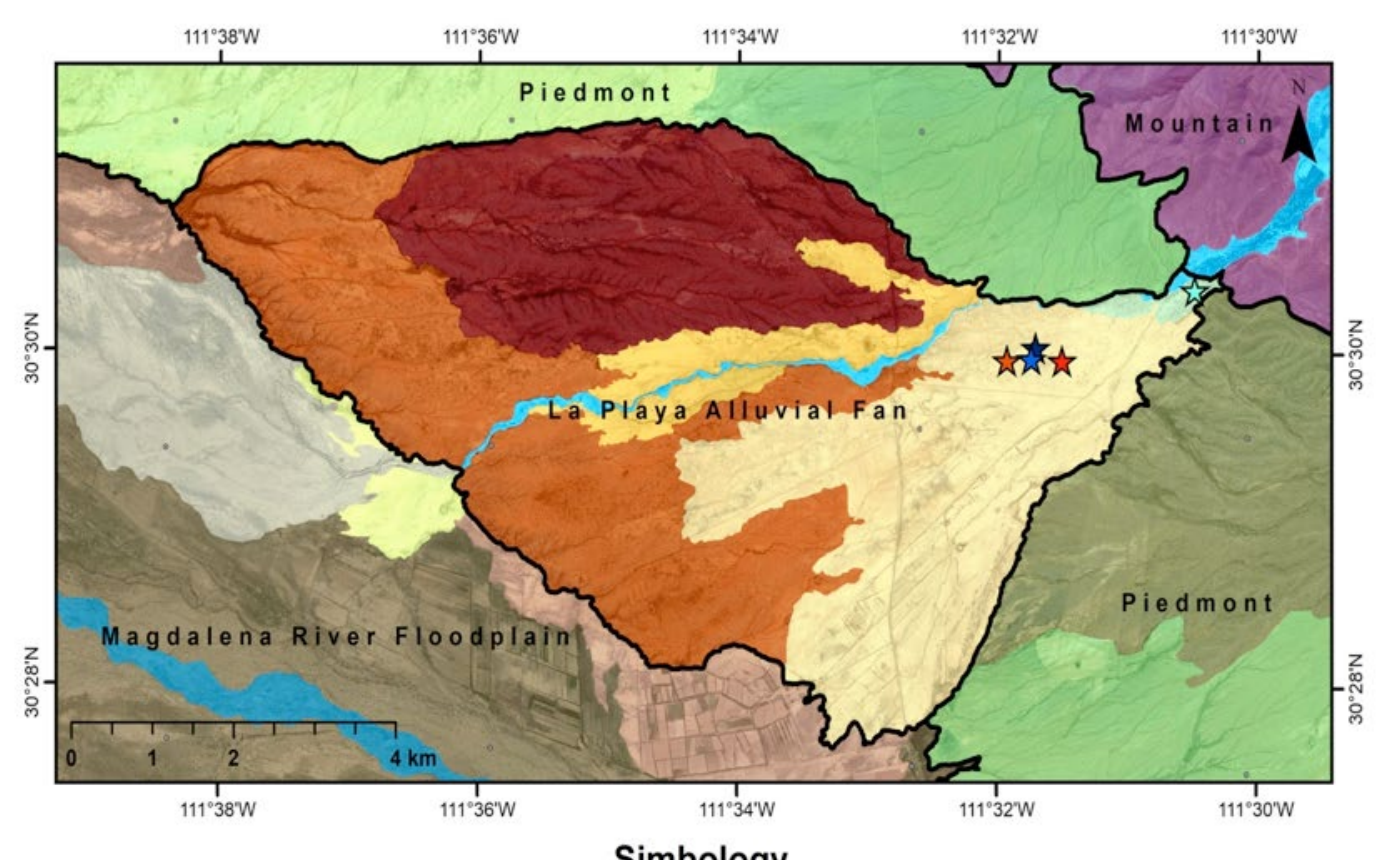

\section{Landforms}

La Playa Alluvia Fan
Feeder channel
Colluvium
BOP surface
Fluvial deposits
SRP surface
Ancient alluvial fan

\section{Magdalena River Floodplain}

Active lobe

$439-462$

2nd Alluvial fan

$452-461$

\section{Simbology}

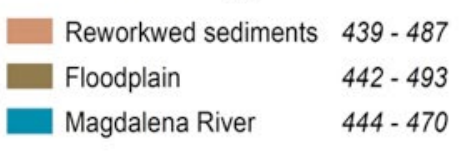

$461-544$

$509-527$

$475-525$

$464-507$

$446-502$

$459-505$

\section{Mountain}

Boquillas Hills

$517-780$

\section{Piedmont}

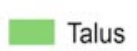

Lateral fan A

Lateral fan B

Lateral fan C

$484-567$

$439-488$

487 - 539

\section{Profiles}

Cruz y Cruz et al. (2014)

it Canal 2

次 Hornos 1

$\star$ Hornos 2

\section{This study}

饮 Maravillas

茨 Zanja 1

Figure 2. Geomorphic units of La Playa. Google Earth. Google Inc. (2016). Google Earth Pro 7.1.7.2606 [Computer software] North of Trincheras, Sonora, Mexico (June 25, 2010). DigitalGlobe 2018. Google Inc. Mountain View, CA. http://www.earth. google.com 
g) The active lobe, the 2nd alluvial fan and the reworked sediments constitute the current progradation from of the alluvial fan. While the reworked sediments are composed of SRP and BOP eroded from alluvial fan surface, the active lobe and the 2 nd alluvial fan are materials coming from the basin.

\subsection{Field descriptions}

\subsubsection{Maravillas profile}

The soil-sedimentary sequence consists of the BOP and the SRP separated by a sedimentary sequence, with the following horizons (from top to bottom): C, 2Ap, 3Ap, 3C, (these horizons constitute the BOP); a sedimentary interval, horizons $4 \mathrm{AC}, 4 \mathrm{C}, 5 \mathrm{C}, 6 \mathrm{BC}$; and the SRP with horizons 7AB, 7Bw (Figure 3 ). The BOP shows gray coloration associated with a higher amount of organic matter. The sedimentary material has a very light brownish coloration; the SRP is reddish brown.

The BOP has a clayey-silt texture in all its horizons. Some differences are observed in the color and structure. The 2Ap and 3Ap horizons are the darkest and show a subangular blocky structure.
The 3Ap has abundant charcoal fragments and is more compact than the 2Ap horizon which has secondary carbonates and rounded rock fragments. The $\mathrm{C}$ horizon in the top includes soil fragments in a silty matrix.

The sedimentary sequence (overlying directly the SRP) includes several facies distributed along the profile, interpreted as lateral accretion sandbars (Lasb), floodplain deposits (FI), central sandbars (Csb), channel (Ch) and floodplain facies (Fp) and four horizons (4AC, 4C, 5C and $6 \mathrm{BC})$. The following is a more detailed description:

- Lasb facies $(130-173 \mathrm{~cm})$ : This facies is sandy with cross lamination which represents lateral accretion sand bars thus a result of a moderate energy flow.

- $\quad$ Fl facies (173-176cm): This facies is silty (> 70\%) with fine plane lamination and small ripples. This facies is interpreted as flood deposits of low energy.

- Csb facies (176-188 cm): This facies consists of sandy sediments with cross-lamination, forming central sand bars, thus representing a flow of moderate energy.

- Ch facies (188-203): This facies is characterized by the presence of pebbles

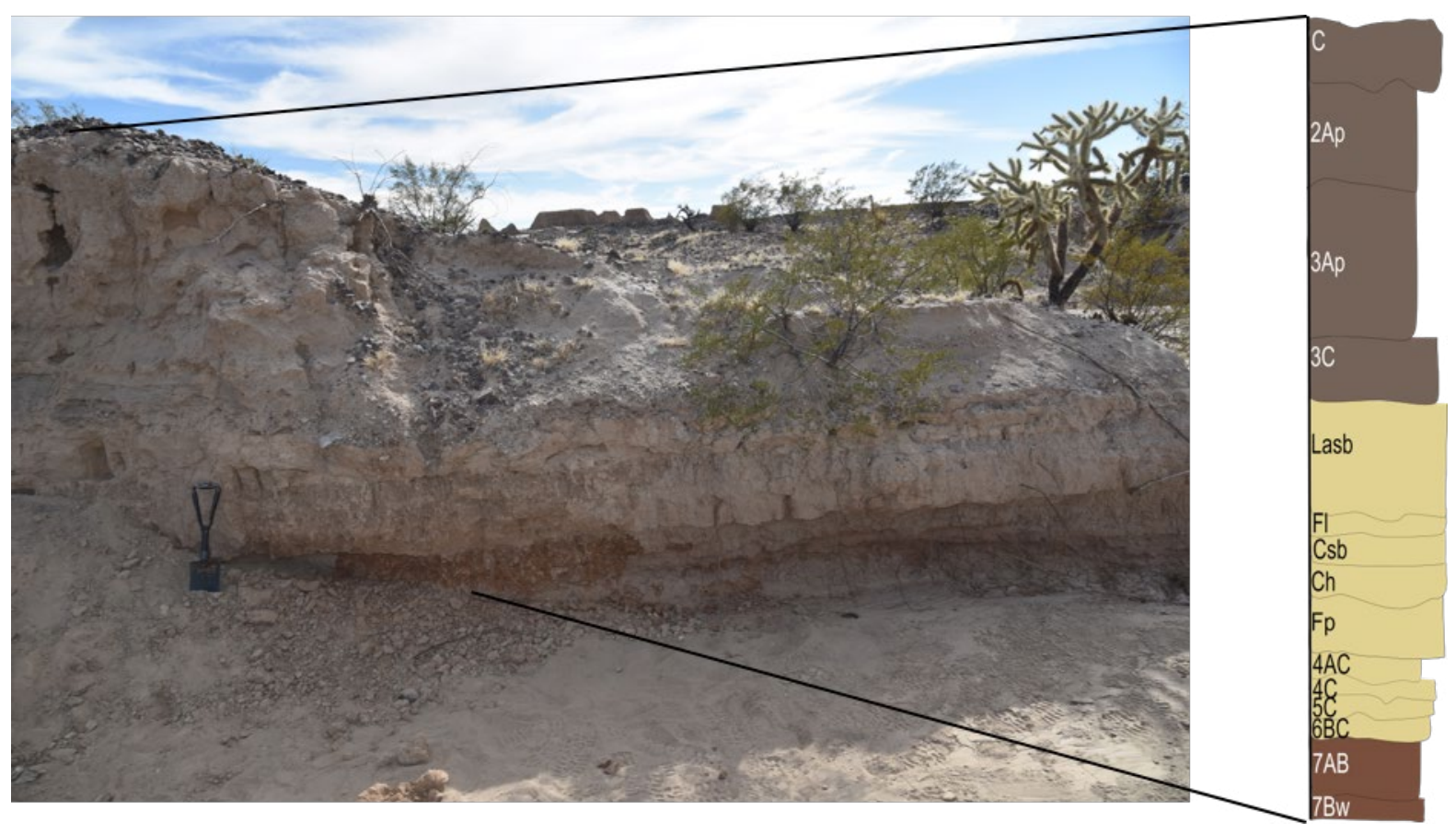

Figure 3. Landscape photo and Maravillas profile. 
supported a sandy matrix with a weak stratification. In some parts an incipient imbrication is detected. This facies represents high energy flows of a channel.

- $\quad$ Fp facies $(203-218 \mathrm{~cm})$ : This is a whitish, silty sediment with a fine lamination and is the result of a low energy flow. It is around $15 \mathrm{~cm}$ thick.

The $4 A C$ horizon is reddish-brown, silty, with a subangular blocky structure. A predominant feature in this horizon is the presence of little fragments of charcoal and carbonates. The $4 \mathrm{C}$ and $5 \mathrm{C}$ horizons are lighter than the previous and siltier, with laminated and oriented material and carbonates inside the root pores. The most remarkable features in $5 \mathrm{C}$ horizon are the presence of clay coatings, and carbonates. The $6 \mathrm{BC}$ horizon is pale reddish brown, sandy with an angular blocky structure that breaks into subangular blocks. Concerning the SRP, The 7AB horizon is less sandy. The 7Bw horizon is more reddish, silty and with a compact angular blocky structure. It has small carbonate and manganese concretions.

\subsubsection{Zanja profile}

The exposed palaeosol consists of the following horizons: C, 2A1, 2A2, 2Bw1, 2Bw2 and 2BCk (Figure 4). This pedostratigraphic unit belongs to the SRP. Almost all horizons of this profile have a similar silty texture, except in the $2 \mathrm{Bw} 1$ horizon where the sandy texture prevails. The $\mathrm{C}$ horizon has a pale brown color and shows fine plane lamination indicative of low fluvial energy. The pedogenic structure is poorly developed. In the dark brown $2 \mathrm{~A} 1$ horizon, the structure is sub-angular blocky. The $2 \mathrm{~A} 2$ horizon has a more complex structure: subangular blocks breaking into granular aggregates. The $2 \mathrm{Bw} 1$ horizon is more compact. It shows a reddish brown color. The texture is a sandy loam and has a strong subangular blocky structure. The 2BCk horizon is pale reddish-brown, silty, and shows a subangular blocky structure.

3.3. Micromorphological observations of selected horizons of studied profiles

\subsubsection{Maravillas profile}

The micromorphological analysis reveals contrasting differences between pedogenic and sedimentary features through the Maravillas profile. The 2Ap horizon of the BOP denotes dominance of blocky microstructure, however some areas show granular aggregation and spongy fabric (Figure 5a). The coarse material is poorly-sorted and consists of silt and minor proportion of sand particles (with preeminence of quartz and plagioclase). Organic matter is present organic pigment in the clayey micromass and

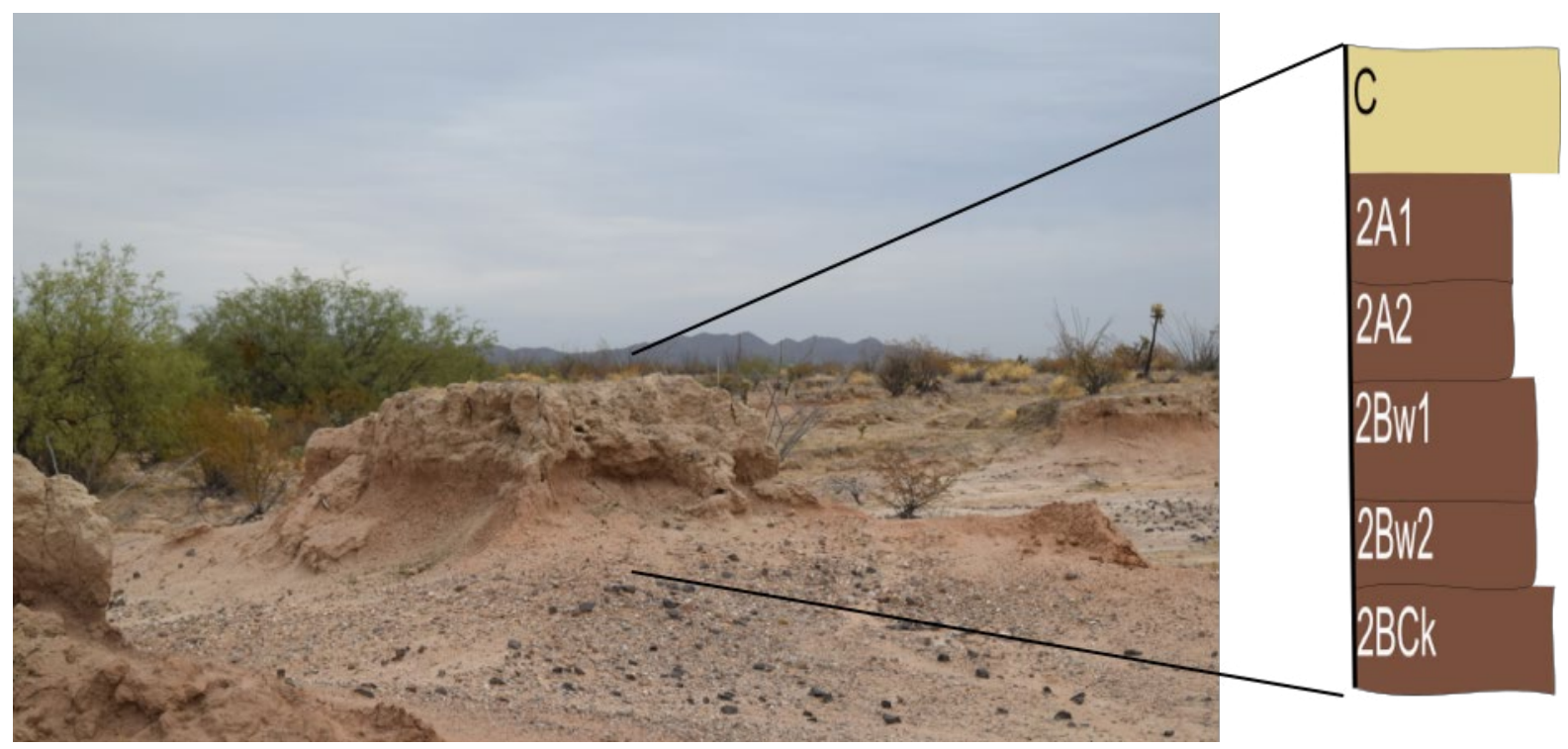

Figure 4. Landscape photo and Zanja profile. 
some charcoal retaining the cellular structure of plant tissues (Figure 5b). In the most uppermost buried humus horizon (2Ap) fragments of bone are present (Figure 5c). Reworked impure silty-clay coatings are common in the unit, particularly in the 2Ap horizon. The 3Ap horizon contains calcite hypocoatings in pore infillings (Figure 5d), gypsum is occasionally present

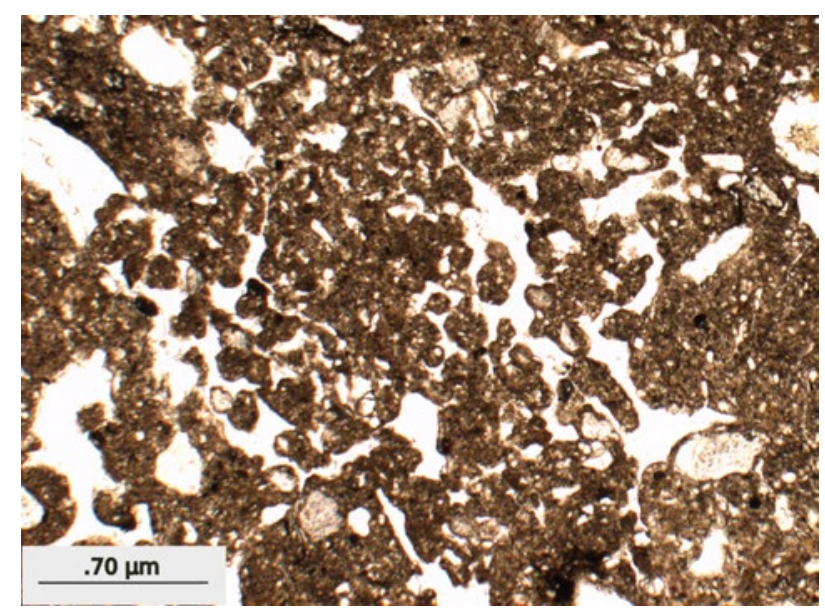

a)

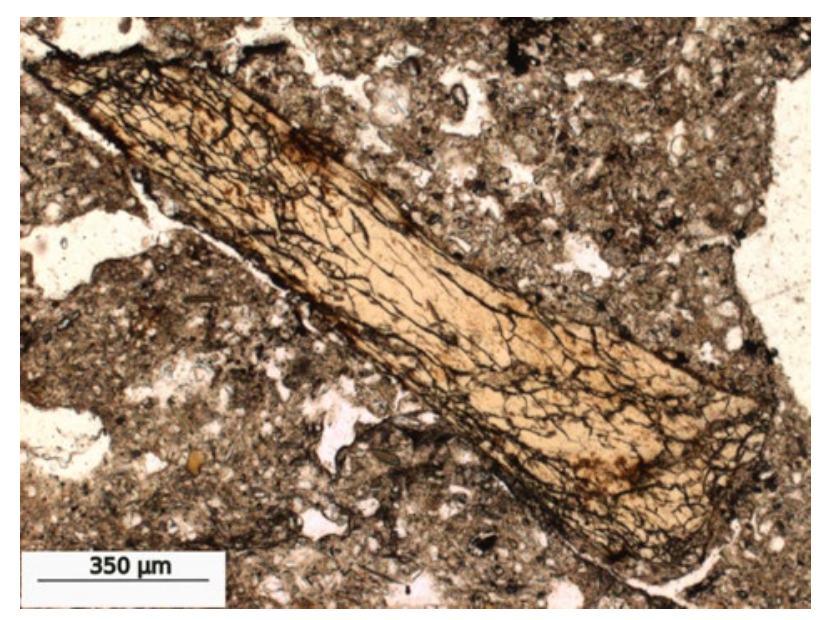

c)

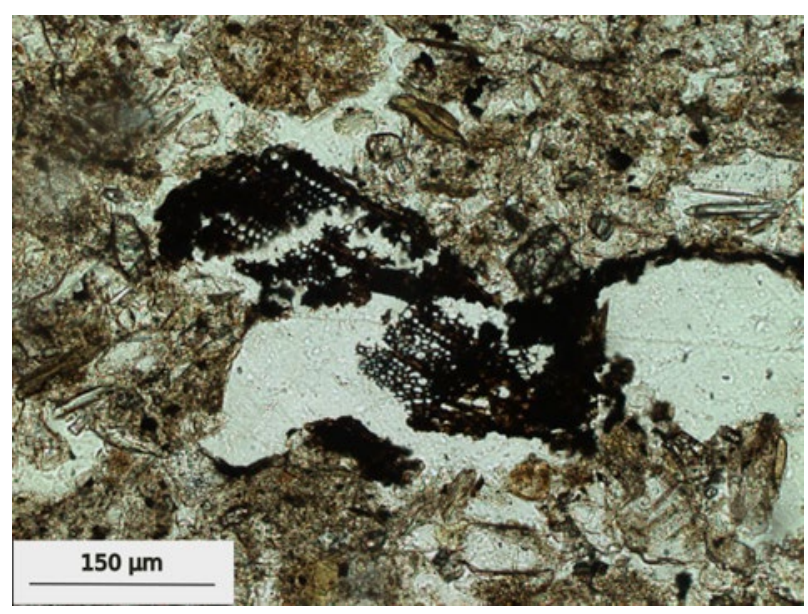

b)

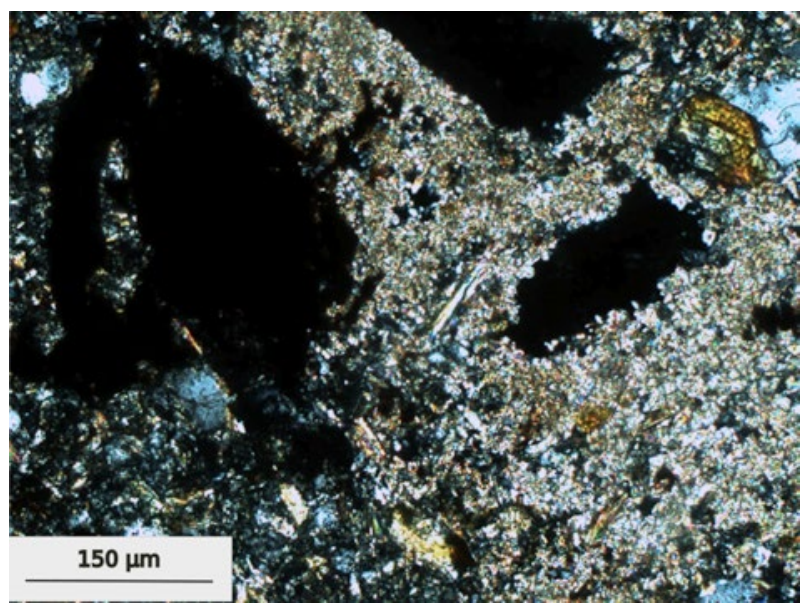

d)

Figure 5. Micromorphology of selected BOP horizons the Maravillas profile. a) Granular aggregation and spongy fabric, 2Ap horizon (PPL - plane polarized light); b) Charcoal fragments with preserved tissue structure, 2Ap horizon (PPL); c) Bone fragment, 2Ap horizon (PPL); d) Calcite hypocoatings in pore infillings, 3Ap horizon (NX).

in this horizon. The presence of reworked or fragmented laminated silty desiccation crusts is very common in the 2Ap and 3Ap horizons.

The Sedimentary Unit is the most diverse regarding pedogenic development. In the upper part of the unit dominated a single grain microstructure; in the lower part we observe a moderately developed sub-angular blocky microstructure. The sandbars facies showed a cross-bedding deposition structures (Figure 6a) typical of current ripples. The lee-side is defined by the presence of opaque minerals; imbrication and normal gradation are common in the central sandbar facies. The same ripple type is found on the top of modern sheet flow deposits in the site. An incipient chitonic $\mathrm{c} / \mathrm{f}$ related distribution is observed: very thin discontinuous clay coatings are present around sand particles. Quartz and feldspars are abundant, mainly from 
schists (with muscovite, chlorite and epidote) and microcrystalline rocks; isolated particles of garnet, volcanic glass, microcline, hornblende and goethite are scarce.

The laminations in the floodplain and channel facies are finer than in other areas of the sequence, with the dominance of quartz-feldspathic silt mineral particles (including well oriented particles of muscovite, biotite and chlorite, resembling zones with a reticular fabric pattern) (Figures $6 \mathrm{c}$ and $6 \mathrm{~d}$ ). An incipient pedogenesis is evident by the presence of root traces and micrite hypo-coatings, as well as redoximorphic ferruginous coatings and mottles (Figures $6 \mathrm{~b}$ and $6 \mathrm{c}$ ). Few fragments of the silty surface crust were observed.

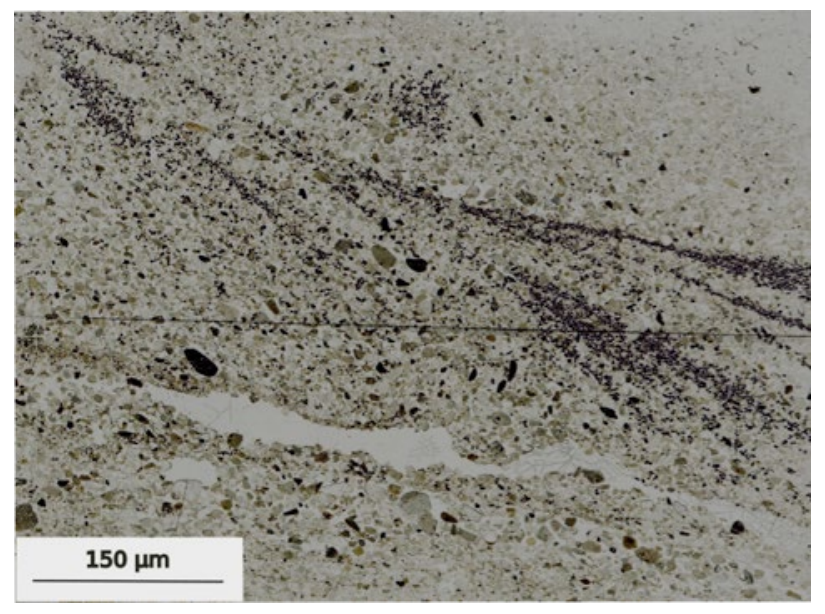

a)

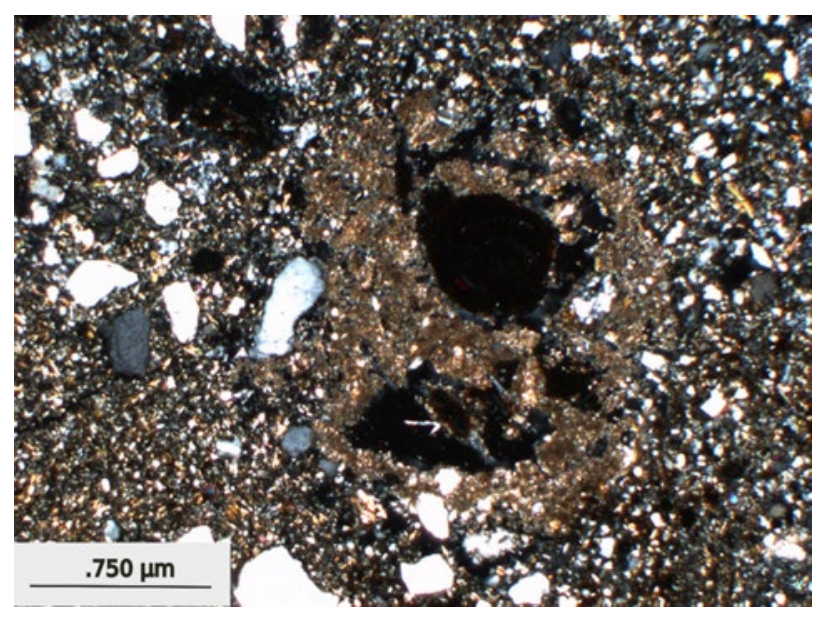

c)
In the lower part, the grain supported microstructure is still present in the horizons $4 \mathrm{C}$ and $5 \mathrm{C}$, enriched in well-sorted silty mineral particles. Particularly in horizon $4 \mathrm{C}$ there are complex areas with coalescent aggregates of biogenic origin (Figure 6e). Charcoal particles are very common, mostly in the upper part of the unit (4AC and $4 \mathrm{C}$ horizons). Secondary carbonates and gypsum are concentrated in the top of the unit: 4AC-4C-5C horizons. In $4 \mathrm{C}$ and $5 \mathrm{C}$ horizons, micritic carbonates are concentrated in pore infillings and sporadic sparite crystals in nodules. Impure silty-humus-clay coatings cover the walls of larger pores in these horizons (Figure 6f).

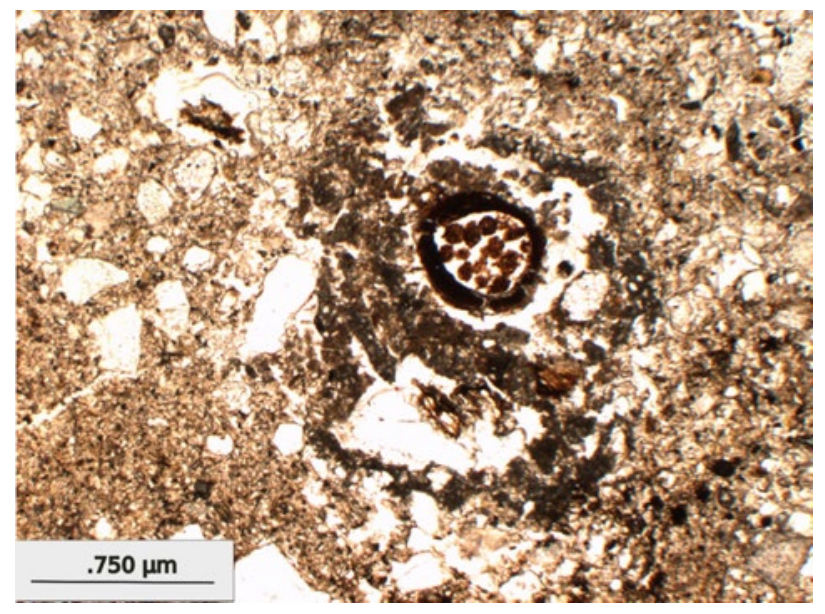

b)

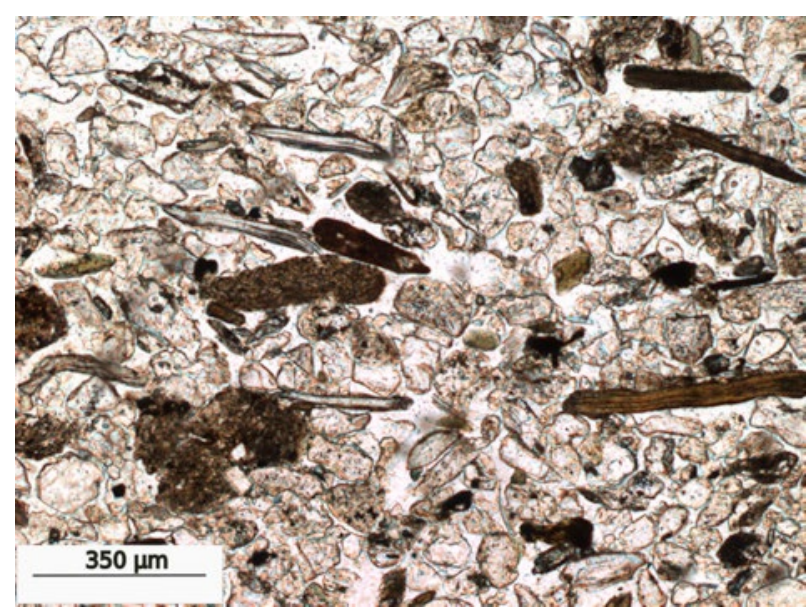

d) 


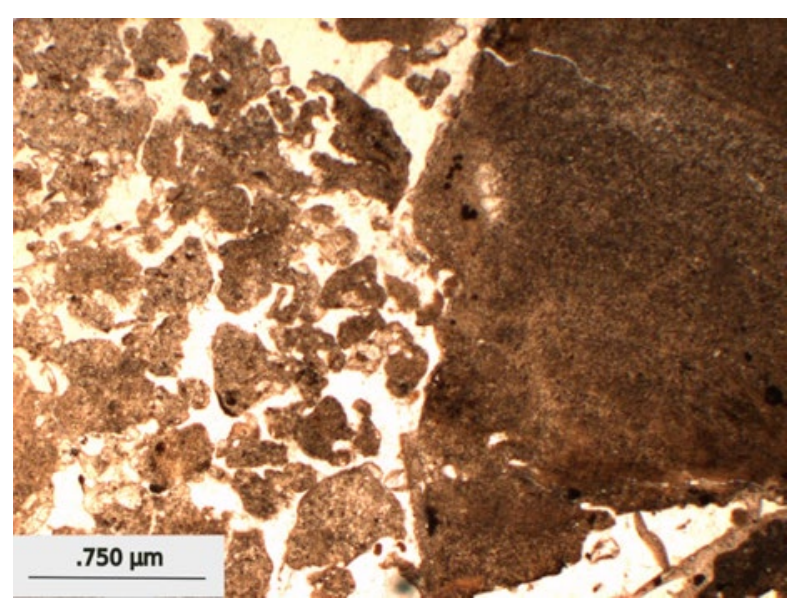

e)

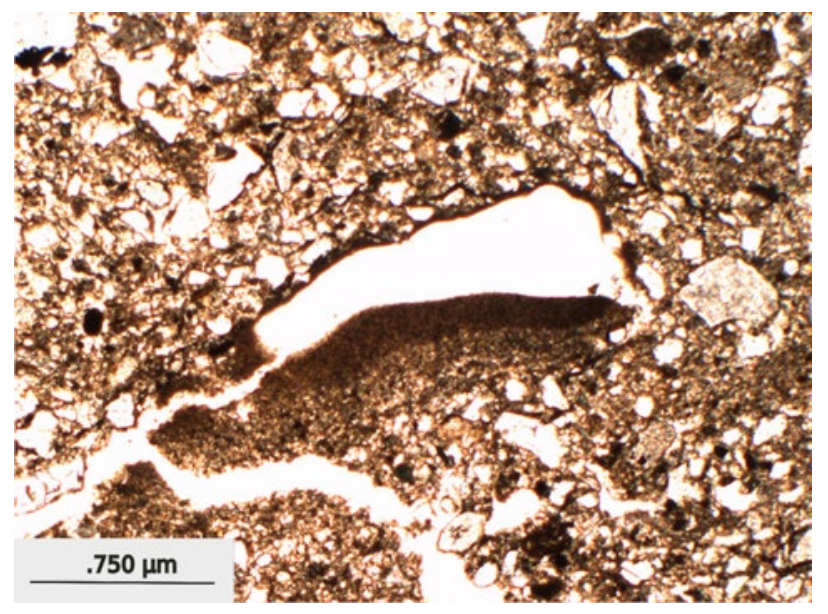

f)

Figure 6. Micromorphology of selected sedimentary unit facies in the Maravillas profile. a) Sandbars facies - crossed lamination horse tale type (PPL); b) Floodplain facies - carbonates associated with coprolites; c) Same as b, with NX (crossed polarizers); d) Channel facies - oriented particles and Fe coating in a pore (PPL); e) Biogenic aggregation and sedimentary material, 4C horizon (PPL); f) Silty-humus-clay coatings, 4AC horizon (PPL).

The SRP Unit is dominated by moderately developed sub-angular blocky microstructure, notably in 7Bw horizons, where thin illuvial clay coatings are deposited over silty and sand particles (Figure 7a). Redoximorphic pedofeatures such as Fe-Mn mottles and nodules in the groundmass are present in the $7 \mathrm{AB}$ and $7 \mathrm{Bw}$ horizons. Thin surface crusts incorporated into groundmass have an important presence in the 7Bw horizon (Figure 7b).

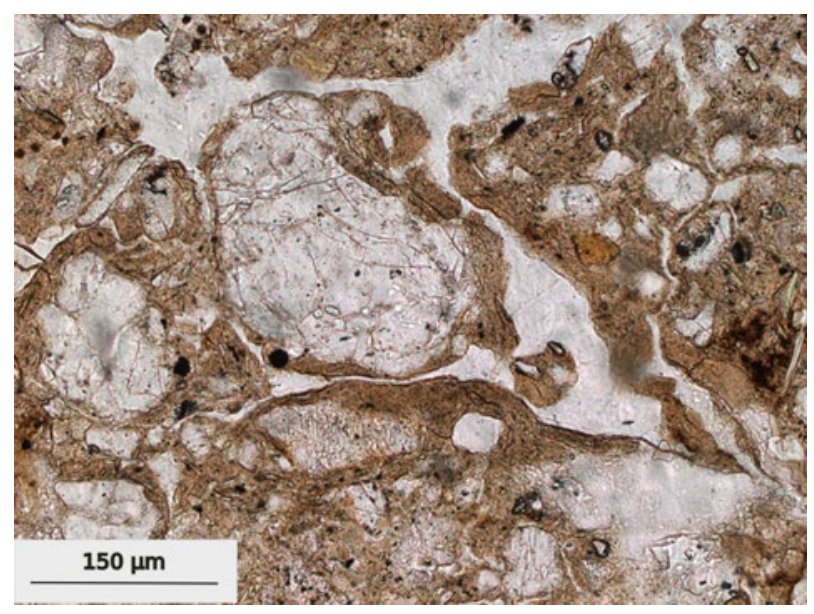

a)

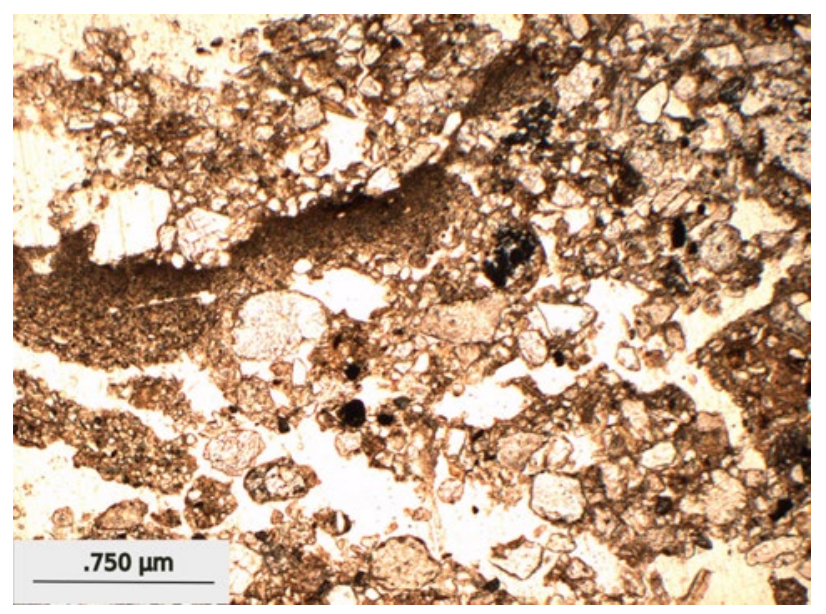

b)

Figure 7. Micromorphology of selected SRP horizons the Maravillas profile. a) Thin illuvial clay coating inside the pores, 7Bw horizon (PPL); b) Fragmented desiccation crust, 7Bw horizon (PPL).

\subsubsection{Zanja profile}

The Zanja profile shows a more complete unit SRP, particularly in the organic horizons. The $2 \mathrm{~A} 1$ horizon presents a more defined microgranular structure with fine humic pigmentation and high porosity. Mesofauna activity is evident by crescent shaped infillings (Figure 8a), the pedogenic micritic carbonates are associated with the crescent shape (Figure 8b). The blocky microstructure of the 2A2 horizon is well differentiated by planar voids; nevertheless, 


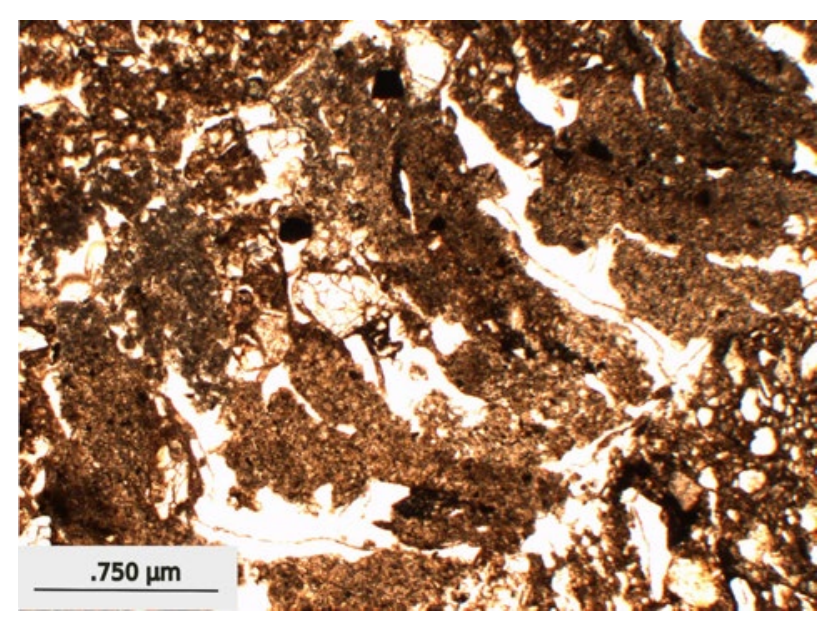

a)

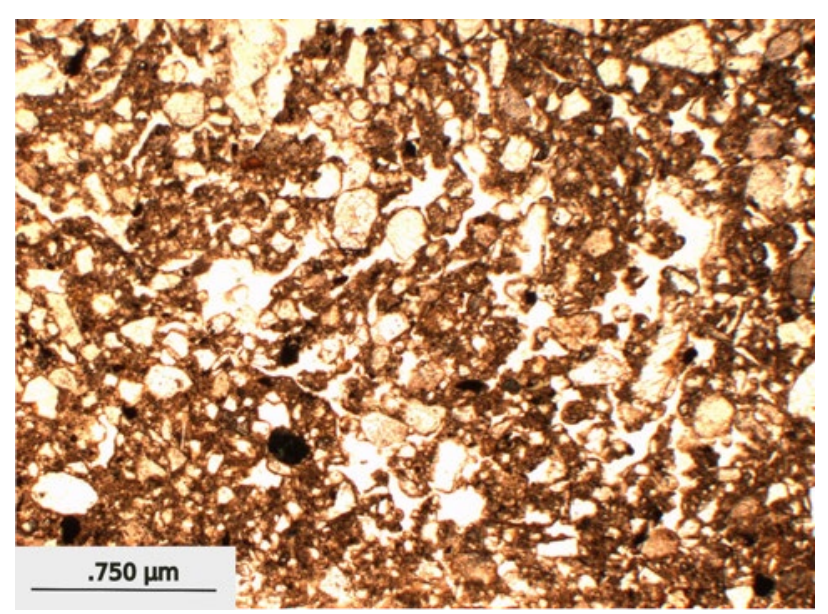

c)

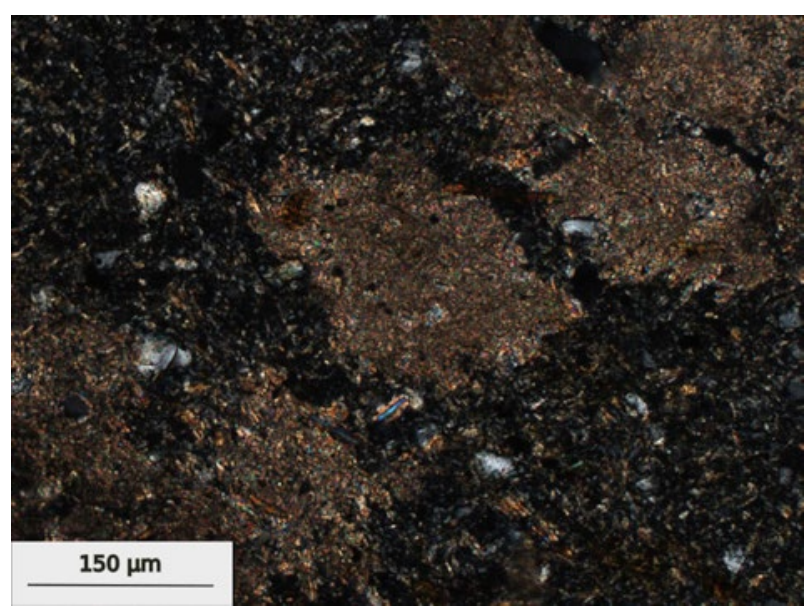

e)

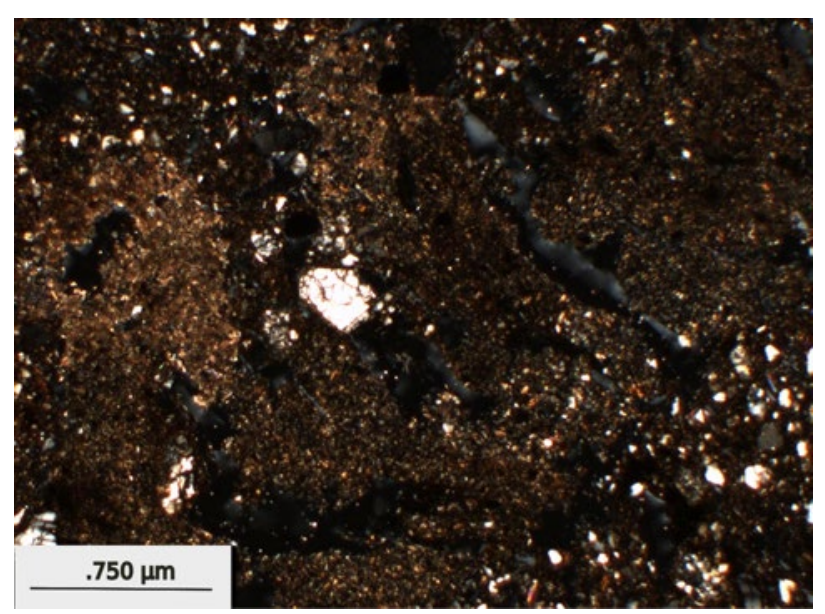

b)

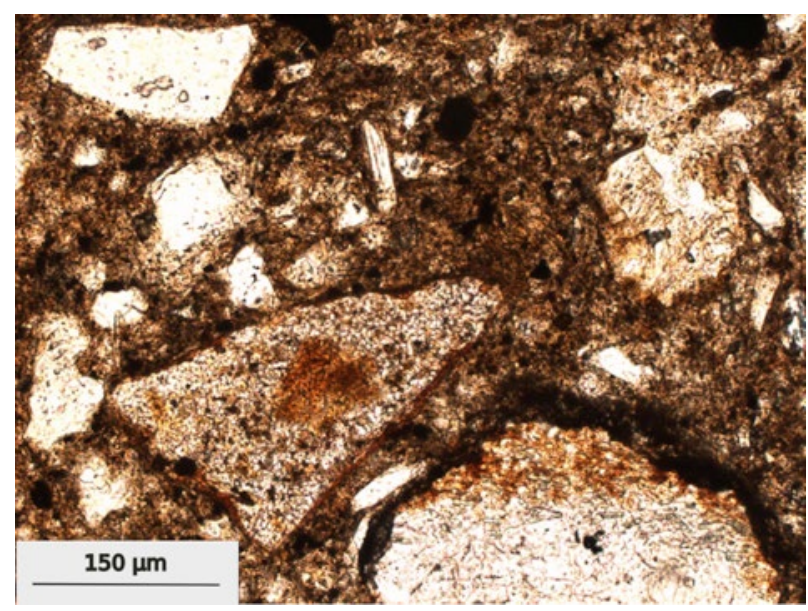

d)

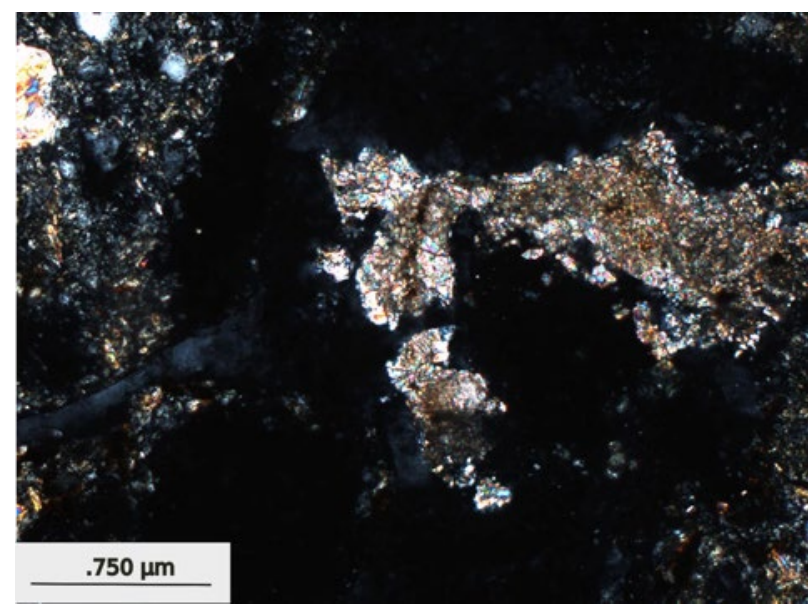

f)

Figure 8. Micromorphology of selected palaeosol horizons in the SRP of the Zanja profile. a) Mesofauna activity in crescent shapes infillings, 2A1 horizon (PPL); b) Crescent shaped carbonates, 2A1 horizon (NX); c) Microgranular biogenic zones, 2A2 horizon (PPL); d) Redoximorphic processes by occurrence of Fe-Mn impregnations in the groundmass, 2Bw horizon (PPL); e) Secondary carbonates, 2BCk horizon (NX); f) Carbonate concretions, 2BCk horizon (NX). 
Table 1. Details of samples and their radiocarbon dates

\begin{tabular}{|c|c|c|c|c|c|c|}
\hline Profile & Horizon & $\begin{array}{l}\text { Dated mate- } \\
\text { rial }\end{array}$ & $\begin{array}{l}\text { Conventio- } \\
\text { nal Age BP }\end{array}$ & $\begin{array}{l}\text { Calibrated } \\
\text { age }\end{array}$ & $\begin{array}{l}\text { Laboratory } \\
\text { code }\end{array}$ & Reference \\
\hline Maravillas & $4 A C$ & Organic matter & $4,070 \pm 70$ & $\begin{array}{c}4,420-4,729 \\
\text { cal BP }\end{array}$ & $\begin{array}{c}\text { ICA- } \\
\text { 16OS/0702 }\end{array}$ & This work \\
\hline \multirow{2}{*}{ Zanja } & $2 \mathrm{~A} 1$ & Organic matter & $4,120 \pm 40$ & $\begin{array}{c}4,526-4,729 \\
\text { cal BP }\end{array}$ & $\begin{array}{c}\text { ICA- } \\
160 S / 0707\end{array}$ & This work \\
\hline & $2 \mathrm{BCk}$ & Carbonates & $5,950 \pm 60$ & $\begin{array}{c}6,659-6,936 \\
\text { cal BP }\end{array}$ & $\begin{array}{c}\text { ICA- } \\
160 S / 0706\end{array}$ & This work \\
\hline Hornos 2 & $3 \mathrm{~A}$ & Organic matter & $3,660 \pm 40$ & $\begin{array}{c}3,880-4,090 \\
\text { cal BP }\end{array}$ & $\begin{array}{l}\text { BETA - } \\
277563\end{array}$ & $\begin{array}{l}\text { Cruz-y-Cruz } \\
\text { et al. } 2014\end{array}$ \\
\hline \multirow[b]{2}{*}{ Hornos 1} & $2 \mathrm{~A}$ & Charcoal & $3,930 \pm 40$ & $\begin{array}{l}4,250-4,440 \\
\text { cal BP }\end{array}$ & $\begin{array}{l}\text { BETA - } \\
300442\end{array}$ & $\begin{array}{l}\text { Cruz-y-Cruz } \\
\text { et al. } 2014\end{array}$ \\
\hline & 3Bgk & Carbonates & $12,490 \pm 60$ & $\begin{array}{c}14,230- \\
14,910 \text { cal } \\
\text { BP }\end{array}$ & $\begin{array}{l}\text { BETA - } \\
277564\end{array}$ & $\begin{array}{l}\text { Cruz-y-Cruz } \\
\text { et al. } 2014\end{array}$ \\
\hline \multirow{2}{*}{ Dos Pisos } & $\mathrm{B}_{0}$ & Charcoal & $4,170 \pm 30$ & $\begin{array}{c}4,610-4,768 \\
\text { cal BP }\end{array}$ & - & $\begin{array}{l}\text { Copeland et } \\
\text { al. } 2012\end{array}$ \\
\hline & $\mathrm{B}_{1} / \mathrm{B}_{2}$ & Charcoal & $3,910 \pm 30$ & $\begin{array}{c}4,280-4,421 \\
\text { cal BP }\end{array}$ & - & $\begin{array}{l}\text { Copeland et } \\
\text { al. } 2012\end{array}$ \\
\hline \multirow{2}{*}{ Los Montículos } & Unit $B_{1-3}$ & Charcoal & $4,040 \pm 110$ & $\begin{array}{l}3,959-4,095 \\
\text { cal BP }\end{array}$ & - & Schott 2017 \\
\hline & Unit $B_{1-3}$ & Humates & $3,430 \pm 30$ & $\begin{array}{l}3,592-3,730 \\
\text { cal BP }\end{array}$ & - & Schott 2017 \\
\hline
\end{tabular}

the coalescent excremental infillings generate locally granular biogenic microzones (Figure $8 \mathrm{c})$, evidenced by fine dark humus pigmentation. The deepest horizons (2Bw1-2Bw2-2BCk) prove the redoximorphic processes by occurrence of Fe-Mn impregnations in the groundmass (Figure $8 d$ ) and ferruginous typical nodules. In the Bw horizons stipple-speckled b-fabric is observed in the clayey fine material, while no primary carbonates were found within the groundmass. Clay illuviation is more evident in the 2Bw2 horizon.

Carbonates are common in the profile, including a micrite component in the groundmass. Some secondary carbonates are related to biogenic channels infillings (2A1 horizon), as well as reworked material. Especially, the 2BCk horizon includes primary and secondary carbonates (Figures 8e, 8f).

\subsection{Radiocarbon dating}

The radiocarbon dates of the selected horizons are shown in Table 1, where dates from other works are included. The age of the $2 \mathrm{~A} 1$ horizon of the Zanja profile is 4,526-4,729 cal BP; and $6,659-6,936$ cal BP for the carbonates found in the $2 \mathrm{BCk}$ horizon. In the Maravillas profile, the age of the $4 A C$ horizon is $4,420-4,729$ cal BP.

\section{Discussion}

4.1. Sedimentation vs. pedogenesis in La Playa from the morphological point of view: evidence of paleoenvironmental conditions

The SRP is the most developed soil in the alluvial fan, reflected by the set of macro and micromorphological features. The parent material is, in consequence, of alluvial origin and is mainly constitutes quartz, rock fragments (conglomerates and sandstones) and ferromagnesian minerals from the Sierra Boquillas (Villalpando et al. 2007). These components are not easily weathered. Although it shows a multi-cycle-welded profile (2A, $2 \mathrm{Bw}$, 
2BCk, 3Bgk, 3C in Hornos 1; 2A1, 2A2, 2Bw1, 2Bw2, 2BCk in Zanja; 7AB, 7Bw in Maravillas), it has a well-developed structure with clay neoformation and accumulation, weathering of the primary minerals and redoximorphic features (Figures 7a, 8d). Additionally, the SRP has abundant pedogenic carbonates with different morphologies, indicating diverse evolutionary stages (Figures $8 \mathrm{~b}, 8 \mathrm{e}, 8 \mathrm{f}$ ). All the $\mathrm{Bk}$ and $\mathrm{BCk}$ horizons have dense carbonates, covering the ped surfaces, as well as nodules. In the thin sections, they form big sparitic crystals (Figure 8f), as well as micrite in the matrix and hypocoatings around the pores. In the upper horizons (2A, 2Bw in Hornos, 2A1, 2A2, 2Bw1 in Zanja, 7AB, 7Bw in Maravillas), some parts of the matrix are decalcified (Figure 8a), but around the pores and passage features, they accumulate (Figure $8 \mathrm{~b}$ ). These features are interpreted as the result of carbonate leaching from the upper horizons to the bottom. These characteristics are the result of weathering, clay illuviation and carbonate migration, which are considered to occur in NX103 years (Targulian and Krasilnikov 2007) that is, moderate-term processes (some millennia). According to the radiocarbon ages (Table 1 ), the pedogenesis period spans around 14,000 years (from > 18,000 , the age of carbonates in SRP-BCk horizon, to 4,200 cal BP, from charcoal and organic matter in the upper SRP horizons). However the age of the upper A horizons in the SRP should be taken cautiously because in most of the area this palaesol is truncated and in the Zanja profile the age comes from the $2 \mathrm{~A} 1$ horizon which shows some micromorphological differences with the 2A2 horizons (Figures 8a and $8 \mathrm{c}$ ), possibly indicating two cycles of soil formation separated in time but until now no instrumental dating is available from the second A horizon.

The 7Bw horizon in the Maravillas profile, showed fragmented desiccation crusts evidencing redeposition processes. On the contrary, in Hornos 1 and Zanja, the SRP suggests a more stable landform. It is probable that Maravillas profile was closer to the active channel during the time of its formation.

Previously, Cruz-y-Cruz et al. (2014) concluded that the SRP was formed under slightly more humid conditions than today. However, these conditions were not continuous in time, it was interrupted and inverted by the aridization trend in the Middle Holocene. The presence of charcoal fragments, reworked desiccation crusts, and micritic carbonates, in the SRP humus horizons supports this conclusion. In consequence, the SRP integrates the information related to the Altithermal conditions. Strong erosion is also evident as most of the SRP profiles have lost their uppermost horizons. These observations are in good agreement to those made by Copeland et al. (2012) who have described the Bo unit, which is of sedimentary origin, as corresponding to this period.

The SRP development is interrupted by a period of instability that produced the next stratigraphic level: the sedimentary unit (Figure 9). The presence of this level is not unexpected in the development of an alluvial fan.

The BOP is composed a poorly sorted alluvial fan sediment with low textural maturity. The sand particles are sub angular and angular, indicating a short distance transport. We also observed fine charred organic particles and impure clay coatings (agrocutans), probably related to the anthropic impact. Palaeosols contain secondary micritic carbonates in pores, and few $\mathrm{Fe}$ and $\mathrm{Mn}$ nodules in the matrix, indicative of weak redoximorphic processes. The upper horizons sowed a fragment of bone, this is associated with human occupation. The presence of clay aggregates with silt material, charcoal fragments and fragments of the surface crust, suggests that the soil was disturbed, possibly as result of manufacturing furnaces (Figure 9).

\subsection{Landscape evolution of the La Playa alluvial} fan

The history of the alluvial fan of La Playa, from the geomorphological point of view, started in the Late Pleistocene when the two oldest landforms were formed (Figure 2): the ancient alluvial fan and the SRP surface. The ancient fan represents the area of the older river channel. It is higher in altitude and highly dissected. The SRP does not appear in this geoform, thus supposing that the SRP is younger than the ancient fan because it is located at a lower elevation (Figure 2), although no absolute dates are available to confirm this supposition. 


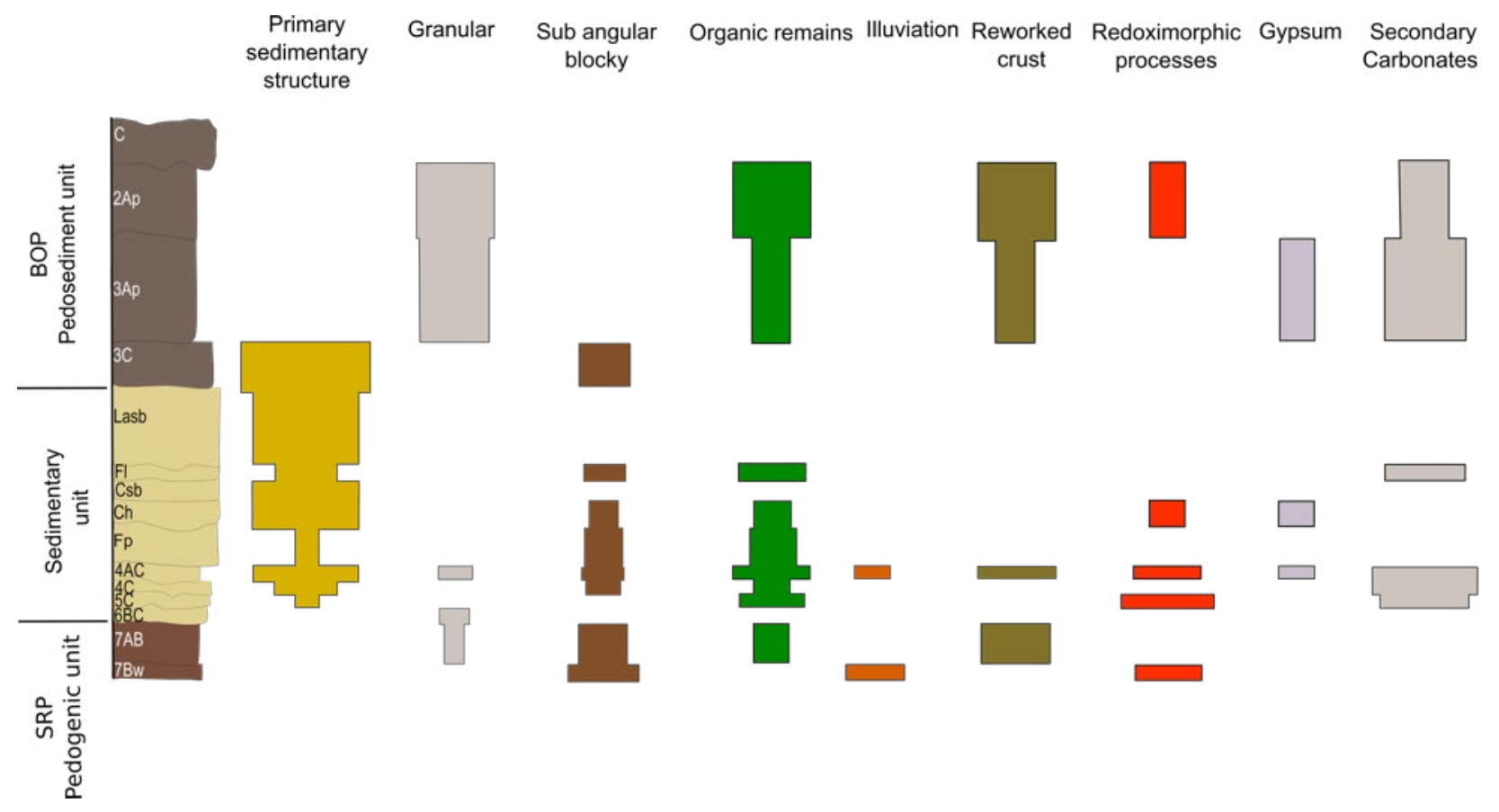

Figure 9. Semi-quantitative differences in the micromorphological properties of BOP, sedimentary unit and SRP in Maravillas profile.

The SRP surface represents a stable area favoring the development of the reddish palaeosol, formed during a long period of landscape stability. According to the instrumental dates, the age from pedogenic carbonates in the Hornos profile is $14,230-14,910$ cal BP (Cruz-yCruz et al. 2014) and from the organic matter of the A horizon in Maravillas and Zanja is 4,250 to 4,729 cal BP. In consequence the estimated time for pedogenesis is around 10,000 years (taking also into account that the pedogenesis of the SRP begins earlier than the carbonate formation). However, the record of the SRP in the area shows a strong erosional phase. Therefore, in most profiles, the surficial horizon is lost (only some pedestals have the rest of its A horizon). This erosional phase can be associated to the beginning of the Altithermal period because the more arid conditions registered during this time caused a diminishing of the vegetation cover allowing rapid erosion. By the end of the Altithermal, temperature decreased, the water saturation increased because of the lessening evaporation, and the runoff increased, favoring the formation of intense floods. The upper part of the SRP in Maravillas is in agreement with this observation.
In the Middle Holocene, the feeder channel abandons the ancient fan and moves to its current position, causing an increase in the sedimentation processes and an abatement in the pedogenesis. After that, a period of high storm intensity and frequency storms occurs, bringing new sediments deposited over the remnant horizons of SRP. Schott (2017) show similar considerations that are registered in other works. These high magnitude events promote the formation of the B0 unit that we consider as the analogue of the sedimentary unit (Copeland et al. 2012). This unit represents the end of the Altithermal. Finally, this period of climatic instability culminates with less frequent sedimentation periods, and more time to develop an incipient pedogenesis between alluvial events. These new sediments and the cumulic soil correspond with the BOP surface. During this time the flooding frequency and magnitude are low (Schott 2017).

There is a controversy around the type of landform that La Playa constitutes. Schott (2017) concluded that the site represents the floodplain of the Rio Boquillas, based on aerial imagery. The author supported this conclusion because 
considers that there is no a distributary channel system, and the sediments do not show evidence of channelized deposition, however the facies analysis is not provided. As we have mentioned, the sedimentary unit, studied here, corresponds to the B0 Unit, proposed by Copeland et al. (2012) and Schott (2017) that shows similar sedimentary facies. Our analysis of the sedimentary facies point to a complex, braided alluvial fan, in which the sediment influx occurs mainly during the rainy season. The set of facies in this unit is not unexpected in the development of an alluvial fan. The thin laminations are typical for floodplain deposits but they are poorly developed and are intersected by different types of central and lateral sand bars (Figures 6a to $6 \mathrm{~d})$ that could correspond to the migration of the main channels.

4.3. From the macro to the regional scale: the influence of pedogenic properties in the geomorphology

Landforms on the alluvial fan are deeply affected by a recent erosional phase that seems to vary according the different palaeosol properties: in the SRP surfaces, rill forms prevail, whereas gullies were dominant in the BOP surface (Figure 2).

Rills and gullies are product of water reworking on the alluvial fans. Rills appear when runoff goes through the fan surface and converge as a consequence of slight topographic and textural variations. Gullies, by the other hand, are a more advance stage of dissection and are produced when water has sufficient energy to detach and transport great portions of soil and sediment particles. Gully depth is limited by the characteristic of the underlying materials and they can be particularly deep on alluvial or colluvial soils (Blair and McPherson 1994; Carey 2006).

It can be inferred from this situation that the advance of pedogenesis in each surface plays an important role in the prevailing style of erosion. Because of a better structure development, SRP has been less affected by water erosion than the BOP, a much younger soil with an incipient structure that makes it highly prone to removal. Furthermore, it is important to consider that most of the time gully erosion is triggered not only by natural factors but also by human impact such as land use change, and in this context BOP is the surface with more evidence of anthropic activity.

\section{Conclusions}

La Playa, from the geomorphological point of view, represents an alluvial fan, with a complex history from the Late Pleistocene (MIS2) to the Late Holocene (MIS1), fed by a migrant braided river. The older surface is characterized by the presence of the ancient alluvial fan, located to the northwest. The SRP are found to the south of the ancient fan, constituting the stable surface. This SRP has a multi-cycledwelded profile, the properties of which are the product of different environmental conditions, with alternation between dry and humid periods. The development of this palaeosol takes place over more than 10,000 years and its pedogenesis is interrupted by a period of strong climatic instability causing erosion of the SRP and sedimentation, presumably during the Altithermal. The sedimentary facies analysis reveals a combination of channel, sandbar and floodplain deposits. This event coincides with the end of the Altithermal period. The younger palaeosol, the BOP, has a strong human impact and shows a more unstable landscape.

\section{Acknowledgements}

This research was funded by the Project CONACYT 236623. We acknowledge the support of the Instituto de Geología, UNAM; Estación Regional del Noroeste, IGL, UNAM; Archaeological Project La Playa of INAH-Sonora (Dir. Villalpando E.). The technical assistance of Jaime Díaz is highly appreciated. Finally, thank for the valuable contributions and comments of Miguel Castillo-Rodríguez, Lorenzo VázquezSelem and Sergey Sedov. 


\section{REFERENCES}

- Antevs E. 1948. The Great Basin: With Emphasis on Glacial and Postglacial times. University of Utah Bulletin V38, No 20.

- Betancourt JL, Van Devender TR, Martin PS. 1990. Packrat middens: the last 40,000 years of biotic change. Tucson: University of Arizona Press.

- Blair TC, McPherson JG. 1994. Alluvial fan processes and forms. In: Abrahams AD, Parsons AJ, editors. Geomorphology of desert environments. London: Chapman \& Hall.

- Bullock, Fedoroff PN, Jongerius A, Stoops G, Tursina T, Babel U. 1985. Handbook for Soil Thin Section Description. Wolverhampton, England: Waine Research Publications.

- Byrne R, Busby C, Heizer RF. 1979. The Altithermal Revisited: Pollen evidence from the Leonard Rockshelter. Journal of California and Great Basin Anthropology $1: 280-294$

- Carey B. 2006. Gully erosion. In: Facts. Land series sheets of the Department of Natural Resources and Water. The State of Queensland. L81. Available in https:// www.qld.gov.au/dsiti/assets/soil/gully-erosion.pdf.

- Carpenter J. 2009. La Playa, Sonora. Arqueología Mexicana Vol. XVII, 97:50-53.

- Carpenter J, Sánchez G, Villalpando E. 2005. The Late Archaic/Early Agricultural Period in Sonora, Mexico. In: Vierra B, editor. New Perspectives on the Late Archaic Across of the Borderlands. Austin: University of Texas Press. p. 3-40.

- Carpenter J, Villalpando E, Sánchez G. 2009. La Playa: an early agricultural period landscape. Archaeology Southwest 23(1):14.

- Copeland A, Quade J, Watson JT, Mclaurin BT, Villalpando E. 2012. Stratigraphy and geochronology of La Playa archaeological site, Sonora, Mexico. Journal of Archaeological Science 39:2934-2944.

- Cruz-y-Cruz T, Sedov S, Sánchez G, Pi-Puig T, Pustovoytov K, Barceinas-Cruz H, Ortega-Guerrero B, Solleiro-Rebolledo E. 2014. Late PleistoceneHolocene palaeosols in the north of Sonora, Mexico: chronostratigraphy, pedogenesis and implications for environmental history. European Journal of Soil Science 65:455-469.

- Gile LH, Grossman RB. 1968. Morphology of the argillic horizon in desert soils of southern New Mexico. Soil Science 106:6-15.

- Holliday VT. 1989. Paleopedology in Archeology. In: Bronger A, Catt JA, editors. Paleopedology: Nature and Applications of Paleosoils. Catena Supplements Volume 16. p. 187-206.
- Holmgren A, Peñalba C, Rylander A, Betancourt L. 2003. A $16,000{ }^{14} \mathrm{C}$ yr B.P. packrat midden series from the USA-Mexico Borderlands. Quaternary Research 60:319329.

- IUSS Working Group WRB. 2006. World References Base for Soil Resources 2006. World Soil Resource Reports no. 103. Rome: FAO.

- Johnson AE. 1960. The Place of the Trincheras Culture of Northern Sonora in Southwestern Archaeology. Master of Science thesis. Department of Anthropology, University of Arizona, Tucson.

- McLaurin BT, Elliott AC, Watson JT, Villalpando E. 2012. Quaternary stratigraphy of the La Playa archaeological site (SON F:10:3), Northern Sonora, Mexico. In: McLaurin BT, Elliot AC, Torres N, editors. Reconstructing humanlandscape interactions. Berlin: Springer Briefs in Earth System Science. p. 3-20.

- Mead JI, White RS, Baez A, Hollenshead MG, Swift SL, Carpenter MC. 2010. Late Pleistocene (Rancholabrean) Cynomys (Rodentia, Sciuridae: prairie dog) from northwestern Sonora, Mexico. Quaternary International 217:138-142.

- Meltzer DJ. 1999. Human responses to Middle Holocene (Altithermal) climates on the North American Great Plains. Quaternary Research 52:404- 416.

- Metcalfe S, Bimpson A, Courtice AJ, O'Hara SLO, Taylor DM. 1997. Climate change at the monsoon/Weterly boundary in Northern Mexico. Journal of Paleolimnology 17:155-171.

- Metcalfe S, Say A, Black S, McCulloch R, O'Hara S. 2002. Wet conditions during the Last Glaciation in the Chihuahuan Desert, Alta Babicora Basin, Mexico. Quaternary Research 57:91-101.

- Nettleton WD, Witty JE, Nelson RE, Hawley JW. 1975. Genesis of argillic horizons in soils of desert areas of the southwestern United States. Soil Sci Soc Am Proc. 39:919-926.

- Nordt L. 2003. Late Quaternary fluvial landscape evolution in desert grasslands of northern Chihuahua, Mexico. Geological Society of America Bulletin 115:596606.

- Ortega-Ramírez J, Valiente-Banuet A, UrrutiaFucugauchi J, Mortera-Gutiérrez C, Alvarado-Valdez G. 1998. Paleoclimatic changes during the Late Pleistocene-Holocene in Laguna Babícora near the Chihuahan Desert, Mexico. Canadian Journal of Earth Sciences 35:1168-1179.

- Pérez G. 1985. Geografía de Sonora. In: Hopkins A, editor. Historia General de Sonora I. Periodo Prehistórico y Prehispánico. Hermosillo, Sonora: Gobierno del Estado de Sonora.

- Schott A. 2017. Site formation processes and depositional environment of a fine-grained alluvial floodplain at La Playa Archaeology Site, Sonora, Mexico. Geoarchaeology 32:283-301. 
- Smith GD, McFaul M. 1997. Paleoenvironmental and geoarchaeologic implications of late Quaternary sediments and paleosols: North-central to southwestern San Juan Basin, New Mexico. Geomorphology 21:107138.

- Targulian VO, Krasilinikov PV. 2007. Soil system and pedogenetic processes: Self-organization, time scales, and environmental significance. Catena 71:373-381.

- Vidal-Zepeda R. 2005. Las regiones climáticas de México. Instituto de Geografía, UNAM, México.

- Villalpando E, Carpenter J. 2004. Proyecto Arqueológico La Playa, VI Informe, Temporada 2003. Análisis de los materiales arqueológicos. Archivo Técnico del INAH (unpublished).

- Villalpando E, Carpenter J, Watson J. 2007. Proyecto Arqueológico La Playa, VIII Informe, Temporadas 2005 y 2006. Archivo Técnico del INAH.

- Weide DL, editor. 1985. Soils and Quaternary geology of the southwestern United States. Boulder, Colorado: Geological Society of America Special Paper 203. 